\title{
Haematological Alterations in Gastrointestinal Helminths Infected Horses at Anand District of Gujarat, India
}

\author{
Prakriti Singh $^{1 *}$, J.J. Hasnani ${ }^{1}$, P.V. Patel ${ }^{1}$, Namrata Singh ${ }^{2}$ and Adesh Kumar $^{3}$ \\ ${ }^{1}$ College of Veterinary Science and A. H., Anand Agricultural University, Anand (Guj.), India \\ ${ }^{2}$ Animal husbandry department, Raigarh (C.G.), India \\ ${ }^{3}$ IVRI, Izzatnagar, Bareilly (U. P.), India \\ *Corresponding author
}

\section{A B S T R A C T}

\section{Keywords}

Horses,

Gastrointestinal

helminthic

infection, Blood

samples,

Haematological

alterations

Article Info

Accepted:

04 March 2019

Available Online:

10 April 2019
A study was conducted to estimate the haematological alterations of gastrointestinal helminthic infection in horses of Anand district of Gujarat, India from March-2016 to February-2017. Based on qualitative faecal examination, a total number of 70 gastrointestinal helminths infected and 70 non-infected blood samples were collected during the clinicodiagnostic approach from horses for study of haematological parameters. The infected horses showed a significant reduction in the mean $\mathrm{Hb}(10.111 \pm 0.13 \mathrm{~g} / \mathrm{dl})$, TEC $\left(6.504 \pm 0.1010^{6} / \mu \mathrm{l}\right)$, PCV $(30.064 \pm 0.42 \%)$, lymphocyte $(39.856 \pm 0.26 \%)$, monocytes $(2.892 \pm 0.06 \%)$ and significant increase in TLC $\left(9.897 \pm 0.1610^{3} / \mu \mathrm{l}\right)$, neutrophil $(52.914 \pm 0.30 \%)$, eosinophil (4.033 $\pm 0.09 \%)$, basophil $(0.302 \pm 0.01 \%), \mathrm{MCH}(15.618 \pm 0.13 \mathrm{pg})$ and MCHC $(33.798 \pm 0.16 \mathrm{~g} / \mathrm{dl})$. The MCV level increased non-significantly in infected horses and recorded as $46.289 \pm 0.46 \mathrm{fl}$.

\section{Introduction}

Parasitic diseases are responsible for the poor health of equine due to their direct effects like irritation, annoyance, intoxication, mechanical obstruction, tissue destruction, competitive food uptake, anaemia, due to which their condition is lost and draught power is reduced. Gastrointestinal parasites, in heavy infection may bring alteration in the normal haematological values among affected animals (Pavord and Fisher, 1987) like neutrophilia, eosinophilia and anaemia (Thamsborg et al., 1998).

\section{Materials and Methods}

The study was done at Veterinary Clinical Complex (VCC), Department of Surgery and Radiology, College of Veterinary Science and A. H., AAU, Anand and the surrounding field areas. Animals were bled from the jugular vein into vacutainer tubes containing EDTA (Ethylene Diamine Tetraacetic Acid) for the 
estimation of various haematological parameters. Haematological studies of the blood samples collected from horses were done by Automatic Whole Blood Analyzer (Mindray BC- 2800 Vet) at the Department of Animal Physiology and Biochemistry, College of Veterinary Science and Animal Husbandry, AAU, Anand. The haematological parameters viz. haemoglobin $(\mathrm{Hb})$, packed cell volume (PCV), total erythrocyte count (TEC), total leukocytes count (TLC), differential leukocyte count (DLC), Mean Corpuscular Volume (MCV), Mean Corpuscular Haemoglobin (MCH), Mean Corpuscular Haemoglobin
Concentration (MCHC) were studied from gastrointestinal helminths infected and noninfected horses.

\section{Results and Discussion}

The infected horses showed a significant reduction in the mean $\mathrm{Hb}$, TEC, PCV, lymphocytes, monocytes and significant increase in TLC, neutrophils, eosinophils, basophils, $\mathrm{MCH}$ and $\mathrm{MCHC}$ as compare to non infected horses. The MCV level increased non-significantly in infected horses. Haematological values were listed in table 1 and figure 1.

Table.1 Haematological values of gastrointestinal helminths infected and non- infected horses

$(\mathrm{Mean} \pm \mathrm{SE})$

\begin{tabular}{|c|c|c|c|}
\hline Sr. no. & Parameters & $\begin{array}{l}\text { Non infected horses } \\
(\mathbf{n}=70)\end{array}$ & $\begin{array}{l}\text { Infected horses } \\
(\mathbf{n}=70)\end{array}$ \\
\hline 1 & $\begin{array}{l}\text { Total Erythrocyte Count (TEC) } \\
10^{6} / \mu 1\end{array}$ & $8.463 \pm 0.18$ & $6.504 \pm 0.10^{*}$ \\
\hline 2 & $\begin{array}{l}\text { Total Leukocyte Count } \\
\text { (TLC) } 10^{3} / \mu 1\end{array}$ & $7.839 \pm 0.22$ & $9.897 \pm 0.16^{*}$ \\
\hline 3 & Haemoglobin $(\mathrm{Hb}) \mathrm{g} / \mathrm{dl}$ & $12.250 \pm 0.19$ & $10.111 \pm 0.13 *$ \\
\hline 4 & Packed Cell Volume (PCV)\% & $38.464 \pm 0.63$ & $30.064 \pm 0.42 *$ \\
\hline 5 & Neutrophils $(\%)$ & $50.695 \pm 0.71$ & $52.914 \pm 0.30 *$ \\
\hline 6 & Lymphocyte (\%) & $42.267 \pm 0.66$ & $39.856 \pm 0.26^{*}$ \\
\hline 7 & Monocytes (\%) & $3.663 \pm 0.10$ & $2.892 \pm 0.06^{*}$ \\
\hline 8 & Eosinophils (\%) & $3.141 \pm 0.09$ & $4.033 \pm 0.09 *$ \\
\hline 9 & Basophils (\%) & $0.232 \pm 0.01$ & $0.302 \pm 0.01 *$ \\
\hline 10 & $\begin{array}{l}\text { Mean Corpuscular Volume } \\
(\mathrm{MCV}) \mathrm{fl}\end{array}$ & $45.561 \pm 0.60$ & $46.289 \pm 0.46 * *$ \\
\hline 11 & $\begin{array}{l}\text { Mean Corpuscular Haemoglobin } \\
\text { (MCH) pg }\end{array}$ & $14.498 \pm 0.18$ & $15.618 \pm 0.13 *$ \\
\hline 12 & $\begin{array}{l}\text { Mean Corpuscular Haemoglobin } \\
\text { Concentration (MCHC) g/dl }\end{array}$ & $31.881 \pm 0.30$ & $33.798 \pm 0.16^{*}$ \\
\hline \multicolumn{4}{|c|}{$(*=\mathbf{p}<0.05, * *=\mathbf{p}>0.05)$} \\
\hline
\end{tabular}


Fig.1 Haematological values of gastrointestinal helminths infected and non- infected horses $(\mathrm{Mean} \pm \mathrm{SE})$

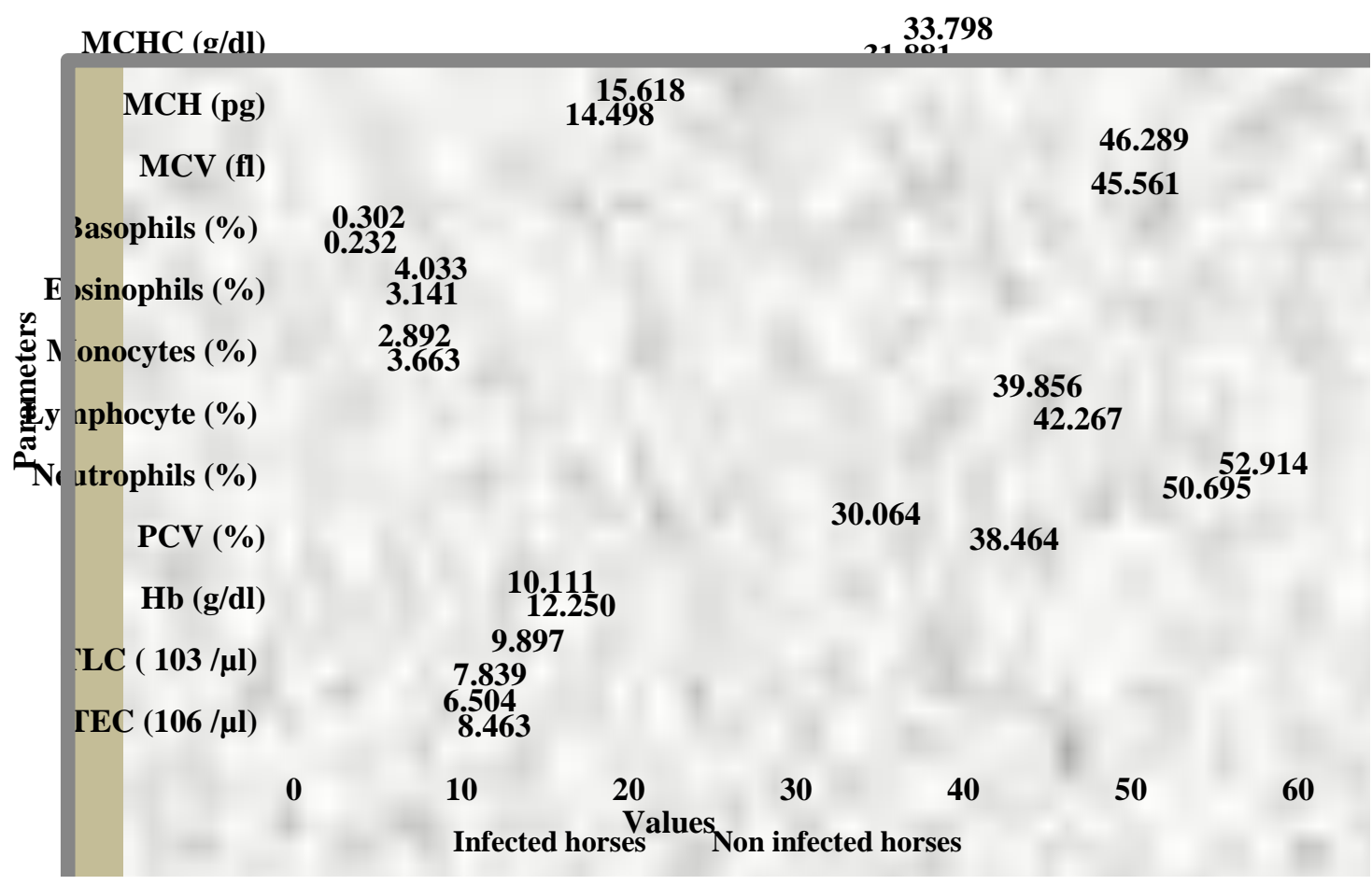

The decreased value of $\mathrm{Hb}, \mathrm{PCV}$ and TEC recorded in the present study could be due to the nature of helminths, particularly of strongyles, which are well known voracious blood suckers which cause direct loss of whole blood (Souls by, 1982; Peal et al., 1989 and Sohail, 1989). Decrease in TEC values might be a result of suppression of erythropoietic activity of bone marrow by parasites (Hayat et al., 1999). Heavy worm loads (strongyles) generally lead to anaemia, caused by both migrating larvae and adult worms to the branches of the intestinal (mesenteric) arteries where they cause damage, irritation and parasitic aneurysmverminous arteritis. The larva causes anaemia by inducing haemorrhagic tracts in the liver parenchyma during migration and also by producing nodules in the wall of caecum and colon. On rupture of these nodules considerable bleeding takes place. Similarly, the adults suck considerable amount of blood causing anaemia (Radostits et al., 2007). The mean value of total leukocyte count (TLC) was significantly increased $(\mathrm{p}<0.05)$ from $\left(7.839 \pm 0.22 \mathrm{t}\right.$ o $\left.9.897 \pm 0.1610^{3} / \mu \mathrm{l}\right)$ in noninfected as compare to infected horses. These findings are in accordance with Kadyrov (1979); McCrow and Slocombe (1985); Esmat et al., (1997); Sipra et al., (1999); Lewa et al., (1999); Hubert et al., (2004); Francisco et al., (2009); Bodecek et al., (2010); Parsani et al., (2011); Singh et al., (2012); Kumar (2012); Kachhawa (2013); Mudgal (2013); Khan et al., (2014) and Salem et al., (2015). In the present study, increased values of total leukocyte count in gastrointestinal parasites infested horses could be due to localized helminths infection and secondary bacterial infection of gastrointestinal tract of horses as stated by Benjamin (1985). This may also attributed to larval migration of helminth parasites via liver and lung. 
The mean value of neutrophils (\%) was significantly increased $(\mathrm{p}<0.05)$ from $50.695 \pm 0.71$ to $52.914 \pm 0.30 \%$ in noninfected and infected horses, respectively. These findings are in agreement with several workers viz. Murphy and Love (1997); Corning (2009); Kumar (2012); Kachhawa (2013); Mudgal (2013) and Khan et al., (2014). Neutrophils are actively amoeboid and phagocytic. They engulf foreign particles and generally digest them. Neutrophils manufacture a trypsin-like enzyme with which they digest foreign particles and dead tissue. When the foreign particle enters in the body, the leukocytes pass out of the blood vessels and surround the threatened area. Neutrophils through their pseudopodial process engulf the foreign particle and destroy them. The phagocytic action of neutrophils may thus, be correlated with their increased number in the present study (Mudgal, 2013). Neutrophils when released into the circulation, has a bizarre, multilobed nucleus and numerous cytoplasmic granules that resembles lysosomes. The granules contain a host of hydrolytic, oxidative and proteolytic enzymes as well as two antibacterial substances, lysozyme and phagocytin. Their function is engulfing and destroying foreign material by phenomenon called as phagocytosis. For phagocytosis of helminth material particles opsonins are required. Opsonins represent the specific antibodies directed against helminthic material. Other functions of neutrophils are secretion of lytic substances to degrade helminth cuticular portions as pathogens (Jones and Hunt, 1983).

The mean value of lymphocytes (\%) was significantly decreased $(\mathrm{p}<0.05)$ from $42.267 \pm 0.66$ to $39.856 \pm 0.26 \%$ in noninfected and infected horses, respectively. These results are in conformity with the findings of Sipra et al., (1999); Kumar (2012); Kachhawa (2013); Mudgal (2013); Khan et al., (2014) and Salem et al.,
(2015).Decreased percentage of lymphocytes were suggestive of active participation of lymphocytes in immune mechanism to evade the helminth antigen. Hence their numbers gradually decreased.

The mean value of monocytes (\%) was significantly decreased $(\mathrm{p}<0.05)$ from $3.663 \pm 0.10$ to $2.892 \pm 0.06 \%$ in non-infected and infected horses, respectively. These findings were in accordance with several workers including Sipra et al., (1999); Kachhawa (2013); Mudgal (2013); Waqas et al., (2014) and Salem et al., (2015). Monocytes are capable of phagocytizing and digesting the particulate matter, such as cellular debris. When foreign body enters in the body these monocytes leave the blood vessels through exocytosis and reach to the tissues and different organs and converted into the macrophages. They are responsible for processing helminth antigen thus enhancing the cell mediated and humoral immunity. These macrophages are capable of digesting and phagocytizing foreign material. Monocytes number is decreased in this study it may be due to their release from blood vessels in massive number and their conversion into macrophages.

The mean value of eosinophils (\%) was significantly increased $(\mathrm{p}<0.05)$ from $3.141 \pm 0.09$ to $4.033 \pm 0.09 \%$ in non-infected and infected horses, respectively. These findings are in line with the findings of Kadyrov (1979); McCraw and Slocombe (1985); Murphy and Love (1997); Sipra et al., (1999); Bodecek et al., (2010); Parsani et al., (2011); Kumar (2012); Kachhawa (2013); Mudgal (2013) Khan et al., (2014); Waqas et al., (2014) and Salem et al., (2015). In the present study, eosinophilia was noticed in the helminth infected horses. The suggested reason is constant irritation caused by the migration of the larvae through intestinal mucosa causing damage and inflammation 
along the way (Leder and Weller, 2000). The increased eosinophil count could be due to local immune response in the gut for the nematodes, which results in circulating and tissue hypereosinophilia (Dawkins et al., 1989). Eosinophils play a definite role in the development of immunity and phagocytosis of the antigen- antibody complex (Litt, 1964). Eosinophils plays an significant role in engulfing foreign materials and helminths. Eosinophils are also thought to play a role in the immune response, possibly accepting antigen or "information" from macrophages that have engulfed antigen. In massive infections, cell counts may increase 10-30 times. Eosinophils have receptors that bind them to antibody and then kill the parasite, presumably through a unique component of the eosinophil granule, the eosinophil major basic protein (MBP). MBP has been shown to kill parasites in vitro (David et al., 1980).

The mean value of basophils (\%) was significantly increased $(\mathrm{p}<0.05)$ from $0.232 \pm 0.01$ to $0.302 \pm 0.01 \%$ in non-infected and infected horses, respectively. These findings are in accordance with Kumar (2012); Kachhawa (2013); Mudgal (2013) and Khan et al., (2014). Basophils and mast cells have similar functions. Basophils and mast cells have FcER receptor which acts as a binding site for $\operatorname{IgE}$ antibody in the cell. When helminthic infection takes place then helminth antigens along with mast cell bound IgE triggers mast cell degranulation and the release of vasoactive molecules and proteases. These molecules stimulate smooth muscle contraction and increase the vascular permeability. The violent contractions of the intestinal muscles and the increase in permeability of intestinal capillaries leading to an efflux of fluid into the intestinal lumen can result in dislodgment and expulsion of many worms (Tizard, 1996). Same way basophils play role against helminth infection.
$\mathrm{MCH}$ and $\mathrm{MCHC}$ values were increased significantly $(p<0.05)$ but there was non significant $(p>0.05)$ increase in MCV values in infected horses as compared to non infected horses. MCV, MCH and MCHC values were higher in infected horses as compared to noninfected horses but these values were within normal range according to the Sastry (1976). In this study haemoglobin ( $\mathrm{Hb})$, total erythrocyte count (TEC) and packed cell volume (PCV) values were reduced in infected horses as compared to non infected horses.

It is suggestive of normocytic normochromic anaemia. Gasser et al., (2004) observed normocytic, normochromic anaemia in horses suffering from strongyloid nematodes.

There is compensatory mechanism in nature in providing the body with adequate amount of erythrocyte aeration surface. Even in the same species, a lower erythrocyte count is made up by an increase in the red cell diameter and hence there is increase in the MCV as well as increase in the MCH (Sastry, 1976).

In conclusion, haematological alterations resulted in normocytic normochromic anaemia, neutrophilia, eosinophilia and lymphocytopenia in infected horses as compare to non infected horses.

\section{Funding}

This study was funded by College of Veterinary Science and A. H., AAU, Anand (Gujarat).

\section{Responsibilities}

Prakritisingh contributed to study design and to data collection, analysis and interpretation. J. J. Hasnani and P. V. Patel contributed for data analysis and interpretation. Namrata 
Singh and Adesh Kumar contributed for data analysis.

All the authors contributed to the preparation of paper and approved the final manuscript for the publication.

\section{Acknowledgement}

The authors are grateful to all the veterinary surgeons that provided samples for the study.

\section{References}

Benjamin, M.M. (1985). Outline of Clinical veterinary Pathology, Kalyani Publisher, New Delhi.

Bodecek, S., Jahn, P., Dobesova, O., and Vavrouchova E. (2010). Equine cyathostomosis: case reports. Veterinarni Medicina, 55(4), 187-193.

David, J. R., Vadas, M. A., Butterworth, A. E., de Brito, P. A., Carvalho, E. M., David, R. A., Bina, J. C., and Andrade, Z. A. (1980). Enhanced helminthotoxic capacity of eosinophils from patients with eosinophilia. N. Engl. J. Med., 303(20), 1147-1152.

Dawkins, H. J. S., Wingdon, R. G., and Eagleson, G. K. (1989). Eosinophils response in sheep selected for high and low responsiveness to Tricostrongylus columbriformis. International journal of parasitology, 14(2), 199-205.

Esmat, M., Abdalla, M., and Selim, M. (1997).Internal parasites of horses and their treatment. Benha Veterinary Medicine Journal, 8, 68-77.

Francisco, I., Sanchez, J. A., Cortinas, F. J., Francisco, R., Mochales, E., Arias, M., Mula, P., Suarez, J. L., Morrondo, P., DiezBanos, P., Sanchez-Andrade, R., and Paz-Silva, A. (2009). Clinical trial of efficacy of ivermectin pour-on against gastrointestinal parasitic nematodes in silvopasturing horses. Equine Veterinary Journal., 41(7), 713715.
Gasser, R. B., Hung, G., Chilton, N. B., and Beveridge, L. (2004). Advances in developing molecular-diagnostic tools for strongyloid nematodes of equids: fundamental and applied implications. Molecular and Cellular Probes, 18(1), 3-16.

Hayat, C. S., Khalid, M., Iqbal, Z., and Akhtar, M. (1999). Haematological and Biochemical disturbances associated with Toxocara vitulorum infection in buffalo calves. Int J Agri and Bio., 1(4), 247-249.

Hubert, J. D., Seahorn, T. L., Klei, T. R., Hosgood, G., Horohov, D. W., and Moore, R. M. (2004).Clinical signs and hematologic, cytokine, and plasma nitric oxide alterations in response to Strongylus vulgaris infection in helminth-naïve ponies. Canadian journal of veterinary research,68(3), 193-200.

Jones, T. C. and Hunt, R. D. (1983).Veterinary Pathology ( $5^{\text {th }}$ ed. $)$. Lea and Febiger, Philadelphia.

Kachhawa, J. (2013). Clinico- therapeutic studies on helminthiasis in horses (Master's thesis, Rajasthan University of Veterinary and Animal Sciences, Bikaner (Rajasthan), India).

Kadyrov, N. T. (1979). Clinic, pathogenesis and pathomorphology of experimental delafondiaosis in foals. Helmintholofia. 16(2), $81-89$.

Khan, S. A., Md. Ashfaque, Fakhruddin and Tanwar, R. K. (2014). HaematoBiochemical Changes in Horses (Equus caballus) Suffering from Gastrointestinal Parasitism. Indian Vet. J., 91(02), $36-39$.

Kumar, L. (2012). Studies on Epidemological, Haemato-biochemical and Therapeutic efficacy of anthelmintic on gastrointestinal parasitism in donkeys (Master's thesis, Rajasthan University of Veterinary and Animal Sciences, Bikaner (Rajasthan), India).

Leder, K., and Weller, F. P. (2000). Eosinophilia and helminthic infections. 
Clinical Haematol., 13(2), 301-317.

Lewa, A. K., Ngatia, T. A., Munyua, W. K., and Maingi, N. E. (1999, September). Comparison of haematological changes and strongyle faecal egg counts in donkeys in Kiambu district of Kenya. Proceedings of an ATNESA Workshop, South Africa.

Litt, M. (1964). Eosinophils and antigen antibody reaction. Annals of new York Academic Science, 116, 964-985.

McCraw, B. M., and Slocombe, J. O. D. (1985). Strongylus equinus: Development and Pathological Effects in the Equine Host. Can. J. Comp. Med., 49(4), 372-383.

Mudgal, N. K. (2013). Some studies on oxidative stress in helminths infested horses (Master's thesis, Rajasthan University of Veterinary and Animal Sciences, Bikaner (Rajasthan), India).

Parsani, H. R., Momin R. R., Lateef, A., and Hemen, D. (2011). Haematobiochemical alterations in helminths infected donkeys. Wayamba Journal of Animal Science, pp 112-114.

Pavord, T., and Fisher, R. (1987). The equine veterinary manual. Crowood Press.

Peal, J. D., Clark, W. L., and Smith, S. (1989). Effect of strongyles on blood parameters. Vet. Bull., 11(2), 503-504.

Radostits, O. M., Gay, C. C., Hinchcliff, K. W., and Constable, P. D. (2007). Veterinary Medicine (10 $0^{\text {th }}$ ed.) W. B. Sanders Co. Ltd., London. Pp. 1558-1564.

Salem, N. Y., Yehia, S. G., and El-Sherif, M. A. (2015). Hemato-Biochemical, and Minerals Status in Mixed Parasitic Infection in Arabian Foals. IOSR J. Agri. Vet. Sci, 8(10), 37-39.

Sastry, G. A. (1976). Veterinary Clinical Pathology. Sastry, G. A., T. V. Press.
Tirupati (A.P.), India.

Singh, G., Soodan, J. S., Yadav, A., Khajuria, J. K., and Agrawal, R. (2012).Evaluation of efficacy of ivermectin and fenbendazole against natural infection of gastrointestinal helminths of equines. J. Vet. Parasitology, 26(1), 66-68.

Sipra, A. S., Anwar, A. H., and Khan, M. N. (1999). Studies on Strongylosis in Equines with special Emphasis on Heamatology and Chemotherapy. Pakistan Journal of Biological Sciences, 2(4), 1624-1634.

Sohail, E. (1989). Studies on the prevalence and taxonomy of the members of Genus strongylus and their effects on the blood picture in equines (M.Sc. (Hons.) Thesis, Deptt. Vet. Parasitol. Uni. Agri., Faisalabad, Pakistan).

Soulsby, E. J. L. (1982). Helminth Arthropods and protozoa of Domesticated Animals ( $7^{\text {th }}$ ed.). The English Language Book Society, Bailliere Tindall, London.

Thamsborg, S. M., Leifsson, P. S., Grondahl, C., Larsen, M., and Nansen, P. (1998).Impact of mixed strongyle infections in foals after one month on pasture. Equine Veterinary Journal, 30(3), 240-245.

Tizard, I. R. (1996). Veterinary immunology. $\left(5^{\text {th }}\right.$ ed.) W. B. Saunders, Philadelphia, PA, U.S.A.

Waqas, M., Khan, M. S., Durrani, A. Z., Khan, M. A., Avais, M., Khan, S. A., and dos Santos, F. C. (2014). Prevalence of Gastrointestinal parasites, chemotherapy and haematology of Strongylosis in Donkeys of District Lahore, Pakistan. Int. J. Curr. Microbiol. App. Sci, 3(7), 198-207.

\section{How to cite this article:}

Prakriti Singh, J.J. Hasnani, P.V. Patel, Namrata Singh and Adesh Kumar. 2019. Haematological Alterations in Gastrointestinal Helminths Infected Horses at Anand District of Gujarat, India. Int.J.Curr.Microbiol.App.Sci. 8(04): 45-51. doi: https://doi.org/10.20546/ijcmas.2019.804.005 